\title{
Chondroitin in Transdermal Patch and Its Main Physical Properties
}

\author{
Iyan Sopyan ${ }^{1 *}$, Moeljadi GT ${ }^{1}$, Saskia Rizky Utami' ${ }^{1}$, Marline Abdassah ${ }^{1}$ \\ Departement of Pharmacetical and tecnolgy of Pharmacy, Faculty of Pharmacy, Padjadjaran
}

State University.

\begin{abstract}
Abstrak
KondroitinSulfat(CS)dalambentuksediaanoraltelahdigunakanuntukmembantumengelolaOsteoarthritis, namun ketersediaan hayatinya sangat rendah yaitu hanya $13 \%$, hal ini disebabkan oleh efek lintas pertama di hati dan untuk menghindarinya diperlukan formulasi CS ke dalam bentuk sediaan lain seperti patch. Penelitian ini bertujuan untuk mengetahui kemungkinan Kondroitin Sulfat (CS) untuk diformulasikan dalam patch transdermal secara in-vitro dan dikarakterisasi sifat fisik seperti profil permeasi melalui studi Franz's Cell dan koefisien partisi. Penelitian menunjukkan bahwa $150 \mathrm{mg}$ CS dalam sediaan patch transdermal memberikan permeasi konstan dalam waktu 19 jam dengan koefisien partisi 2,22. Berdasarkan profil permeasi dan studi koefisien partisi, patch CS akan menjadi sediaan efektif untuk dipertimbangkan.
\end{abstract}

Kata kunci: Kondroitin sulfat (CS), patch transdermal, profil permeasi, koefisien partisi.

\begin{abstract}
Chondroitin Sulphate (CS) in oral dosage form has widely used to help manage Osteoarthritis, but regret its bioavailability was very low at only $13 \%$, It was due to the first passed effect in the liver and to avoid it CS is needed to be formulated into another forms of preparation like Patch. This study was aimed to figure out in-vitro possibility of Chondroitin sulphate (CS) to be formulated in a Transdermal patch and characterized by its physical properties such as permeation profile through the Franz's Cell and partition coefficient studies. The study showed that $150 \mathrm{mg}$ CS in Transdermal patch given the constant Permeation within 19 hours with the Partition Coefficient of 2.22. Based on the permeation profile and the partition coefficient study, the CS patch would become an effective preparation to be considered
\end{abstract}

Keyword : Chondroitin Sulphate (CS), Transdermal patch, Permeation profile, Partition coefficient 


\section{Introduction}

Osteoarthritis is a condition that affects the joints, causing pain and stiffness, by far it's the most common joint disease affecting people all over the world, which was caused by inflammation, breakdown, and the eventual loss of cartilage in the joints (the cartilage wears down over time). Almost anyone, usually woman, over 40 year old, overweight, had previous joint injury or damaged joints by another disease (like gout or rheumatoid arthritis) can get osteoarthritis. (Arthritis Foundation, 2007)

There's no instant cure for osteoarthritis but there's good evidences that changing the lifestyle, applying nutritious diet, losing weight, doing daily exercises, reducing stress on the affected joint, applying pain killer creams or gels, taking NSAID or steroid injections, surgery for knee and hip replacement, using complementary medicine, applying pain management and relaxation techniques, may help easing joint pain. (Medlineplus, 2016) Nutraceuticals are good candidates for long-term prevention of chronic OA, which could help to maintain bone and joint health,

Chondroitin is a complex carbohydrate naturally occurring compound which is one of the most vital compounds in connective tissue responsible for building and supporting the ground substance provides support for strong, healthy cartilage and joints. Decrement of chondroitin at the cartilage tissue made up the Osteoarthritis (Tan, 2008)

Chondroitin sulphate (CS) is produced from enzymatic digestion of bovine and marine animal tissues, specifically bovine nasal septum and trachea, and shark cartilage. Supplemented of Chondroitin Sulphate may stimulate the production of collagen in the body which help maintained water and padded for the joints, by moderating healthy enzyme activity giving beneficial effect on degenerated joints, improving symptoms and stopping (or possibly reversing) the degenerative process of osteoarthritis even protect cartilage. CS and other compounds, such as glucosamine, have been used for medicinal purposes for over 40 years. CS is sold as over the counter dietary supplement. CS has raised many interests over the past decades as a potential therapeutic against OA. CS is part of the Osteoarthritis Research Society International (OARSI) recommendations for the management of knee OA (Zhang et al. 2010, 2008) and of the European League Against Rheumatism (EULAR) recommendations for the management hip and knee OA.

CS is mostly administered orally at doses ranging from 800 to $1200 \mathrm{mg}$ /day. CS is rapidly absorbed by the gastrointestinal tract. The absorbed CS reaches the blood compartment as 10\% CS and 90\% depolymerized low-molecular weight derivatives, due to the liver first-pass effect. (Lockwood, 2007). Different bioavailability and pharmacokinetic variables have been reported depending on the CS characteristics and origin (Malavaki et al. 2008)

The bioavailability of CS ranges from $10 \%$ to $20 \%$ following oral administration (Lauder, 2009) This low bioavailability concluded that there's only insignificant trace amounts of CS enter human serum after oral ingestion which's far below any amount that could make significant therapeutic contribution, besides that oral ingestion of CS will be limited by other side effects such as gastric irritation, nausea and gastric ulceration.

Due to the situation, we were here tried to introduce Transdermal Patch, a novel alternative of delivery system, although no independent clinical evaluation on the efficacy and safety of the formulation has been carried out aimed to reduce API from the decrement of its bioavailability, giving the systemic effect free from liver's firstpass effect and GI disturbances, API which are introduced transdermally may enter the body through the skin, either transellular or intercellular, The Transdermal dosageform basic formula were consist of a polymer matrix, penetration enhancer, humectant 
and preservative (Scheindlin, 2004). From the patient point of view, transdermal delivery would be more convenient rather than oral or parenteral one, which avoided from frequent dose administration, allow self-usage, reduces side effect, improves patient compliance (Aggarwal, 2013)

\section{Materials and Methods}

Materials

Materials which was used were: Potassium dihydrogen phosphate (E.Merck) Sodium Hydroxide (E.Merck), Chondroitin Sodium Sulphate (EkaCittaDianPerkasa) Sodium Lauryl Sulphate (Bratachem), n-Octanol (Bratachem), Poly Vinyl Pyrolidone (Megasetia Agung), dried Python Morulus skin (Bandung Zoological Garden)

\section{Equipment}

Laboratory equipment which we used was Franz Diffusion Cell (FTFlab), UVVis spectrophotometer (Specord 200-222 U170), Analytical Balance (Dragon204), Peristaltic pump (FischerScientific), Magnetic Stirrer (Yellow MAG-HS7), Flat Glass Patch Mold \& General Laboratory glasswares (SCHOTZ)

CS patch preparation method

Transdermal patches used in the study was provided from the market (2) and made (1) from PVA-PVP based according to the formula as configured in table 1 .
Determination of Permeation Profile

In-vitro CS release was done by Franz Cell Diffusion Method in 24 hours, test samples was taken 1 hourly and measured using validated spectrophotometry (salerno, 2010).

Determination of Partition Coefficient $150 \mathrm{mg}$ Pure CS and Sample patches each was transferred to the shaking bottle, shaked for 30 minutes with equal portion of water and n-Octanol, then checked the CS content in each phase after separation (Nice, 2007)

Data Analysis and interpretation

The results were analyzed by looking at the means \pm standard deviation (SD). Statistical analysis using SPSS v.15.0 statistical software (one-way ANOVA) for comparison between each patch with significant level of $95 \%(\mathrm{p}<0.05)$

\section{Results and Disscusion}

Gross inspection at the time of retrieval revealed a yellowish appearance of the patch with good condition.

\section{Permeation profile of CS patch}

Permeation is the main characteristic of the patch formulation, permeation profile served at (table.2), showed 100\% of CS permeated in 19 hours. patch 1 was formulated CS patch (project) and Patch 2 wss commercial product contained

Table 1. Formulation of CS patch

\begin{tabular}{cc}
\hline Formulation & Quantity (g/100 g) \\
\hline Chondroitin sulphate & 0.15 \\
NaOH & 0.6225 \\
PVP : PVA (30:70) & 10 \\
Propylene glycol & 30 \\
\hline Sodium Lauryl Sulphate & 3 \\
\hline Ethanol 95\% : water $(70: 30)$ & Added to $100 \mathrm{~g}$ \\
\hline
\end{tabular}


Table 2. Permeation profile of the Patches, measuring samples were taken hourly (20 h)

\begin{tabular}{|c|c|c|}
\hline \multirow{2}{*}{$\begin{array}{l}\text { TIME } \\
\text { (HOUR) }\end{array}$} & \multicolumn{2}{|c|}{ (\%) PERMEATION } \\
\hline & $\begin{array}{l}\text { Patch } 1(\mathrm{n}=3) \\
\mathrm{X}(\text { mean }) \pm \mathrm{SD}\end{array}$ & $\begin{array}{c}\text { Patch } 2(\mathrm{n}=3) \\
\mathrm{X}(\text { mean })\end{array}$ \\
\hline 1 & $19.9849 \pm 0.4$ & $20.242 \pm 0.1$ \\
\hline 2 & $22.0419 \pm 0.4$ & $22.638 \pm 0.4$ \\
\hline 3 & $24.8418 \pm 0.2$ & $25.710 \pm 0.3$ \\
\hline 4 & $24.8418 \pm 0.1$ & $28.078 \pm 0.2$ \\
\hline 5 & $27.8639 \pm 0.2$ & $38.499 \pm 0.5$ \\
\hline 6 & $35.8215 \pm 0.1$ & $40.775 \pm 0.3$ \\
\hline 7 & $40.0926 \pm 0.2$ & $43.368 \pm 0.1$ \\
\hline 8 & $42.6683 \pm 0.2$ & $45.978 \pm 0.2$ \\
\hline 9 & $45.5773 \pm 0.2$ & $49.328 \pm 0.2$ \\
\hline 10 & $48.6451 \pm 0.1$ & $53.548 \pm 0.1$ \\
\hline 11 & $52.5351 \pm 0.2$ & $60.156 \pm 0.1$ \\
\hline 12 & $59.7308 \pm 0.2$ & $67.398 \pm 1$ \\
\hline 13 & $65.3373 \pm 0.3$ & $73.303 \pm 0.2$ \\
\hline 14 & $69.9664 \pm 0.2$ & $79.364 \pm 0.2$ \\
\hline 15 & $77.2447 \pm 0.4$ & $85.245 \pm 0.2$ \\
\hline 16 & $83.6892 \pm 0.2$ & $89.674 \pm 0.2$ \\
\hline 17 & $87.9336 \pm 0.1$ & $96.505 \pm 0.2$ \\
\hline 18 & $93.0903 \pm 0.2$ & $98.312 \pm 0.2$ \\
\hline 19 & $98.5715 \pm 0.1$ & $99.439 \pm 0.5$ \\
\hline 20 & $99.8623 \pm 0.1$ & $98.206 \pm 0.2$ \\
\hline
\end{tabular}

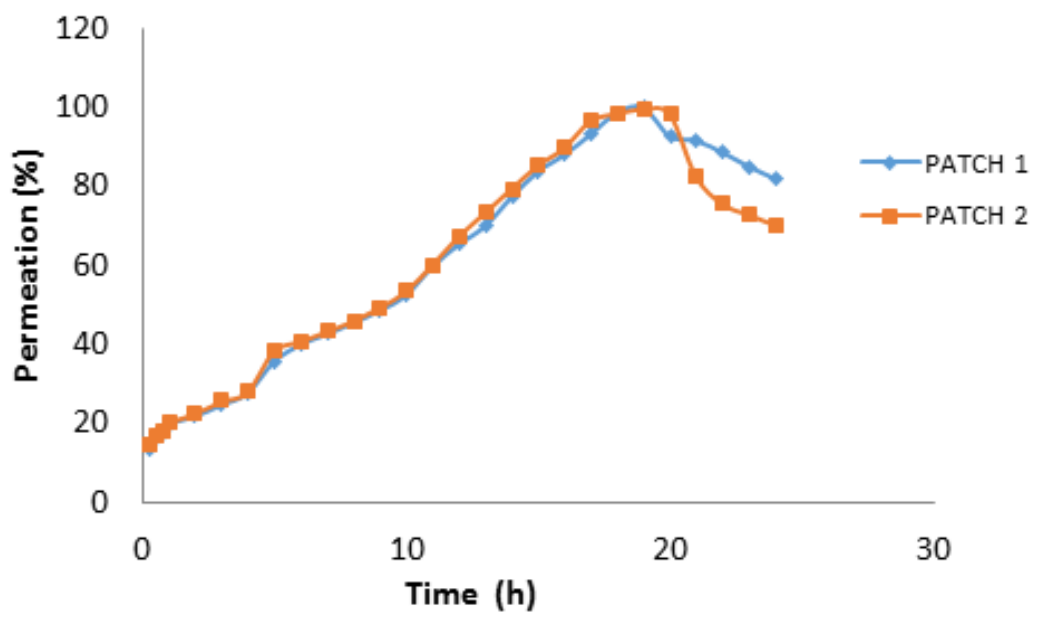

Figure 1. Patch Permeation vs time curves. Maximum permeation (99\%) was reached at 19 hours.

chondroitin (standard)

Comparison of the test patch (1) to the standard (commercial patch (2) has been done by using SPSS ver.15.0, results of the statistical $(\alpha=0.05)$ test showed that $\mathrm{p}$-value was $>0,502$. Its meant there was no significant difference between both patches, and formulation of patch 1 showed 
Table 3: Statistic test result of Patch 1 and patch 2

\begin{tabular}{lllc}
\hline Group & $\mathbf{X}($ mean $) \pm \mathbf{S D}$ & T Calculated & p-value \\
\hline Patch 1 & $2.693 \pm 3.904$ & 0.683 & 0.05 \\
Patch 2 & $2.173 \pm 5.449$ & 0.502 &
\end{tabular}

Table 4: Partition coefficient of Chondroitin Sulphate

\begin{tabular}{cc}
\hline Sample & Partition Coeffiecient \\
\hline Chondroitin sulphate & 2.13 \\
Patch 1 & 2.22 \\
Patch 2 & 2.22
\end{tabular}

permeation release as good as standard patch.

Determination of Partition Coefficient

The importance of the determination of partition coefficient on Pure CS and patch samples were to gather the relative lipophilicity of the CS, even n-Octanol was not biological molecule, but at least it's suitable for the partition study of the drug molecule between water and phospholipid layer, since the drug's optimum partition in lipid layer is the key factor in developing pharmaceutical products (Rak, 2013)

Based on tabel 4, it was showed that, the increment of partition coefficient of both patches logically would be contributed to the higher CS permeation.

\section{Conclusions}

Patch preparation of CS has been done and can be considered for developing into commercial product as a subtitution for oral preparation of the CS. Beside the simplicity of the administration.

\section{Acknowledgment}

This research received no specific grant from any funding agency in the public, commercial, or not for profit sectors.

\section{References}

[1] Aggrawal G, Shanju D, Kumar SLH. Formulation, in vitro and in vivo evaluation of transdermal patches containing risperidone. 2013;39(1):39-50

[2] Arthritis Foundation. 2007. Osteoarthritis. [accessed at 16 Januari 2012]. Available at : http:// www.arthritis.org/disease-center. php?disease_id $=32 \& d f=$ definition

[3] Lockwood, B. Nutraceuticals. 2nd ed. Manchester, UK: Pharmaceutical Press. 21. 2007

[4] Lauder RM. Chondroitin sulphate: A complex molecule with potential impacts on a wide range of biological systems. Complement Therapies Med. 2009;17:56-62

[5] Malavaki CJ, Asimakopoulou $\mathrm{AP}$, Lamari FN, Theocharis AD, Tzanakakis GN. Karamanos NK. Capillary electrophoresis for the quality control of chondroitin sulfates in raw materials and formulations. Anal Biochem. 2008;374:213-220.

[6] Medlineplus. Joint Health and Care: Prevention, Symptoms, Diagnosis \& Treatment. 2016. [accessed at 02 November 2016]. [available at https:// medlineplus.gov/magazine/issues/ spring09/articles/spring09pg14.html]

[7] Salerno C, Carlucci AM, Bregni C. Study of in vitro drug release and percutaneous absorption of fluconazole from topical dosage forms. AAPS PharmSciTech. 
2010;11(2):986-993

[8] Nice. Guidance on osteoarthritis. 2007. [accessed at Nov 03, 2016]. [available at http://www.nice.org.uk/ cg59]

[9] Rak J, Dejlová B, Lampová H, Kaplánek R, Matějíček P, Cígler P, et al. On the solubility and lipophilicity of metallacarborane pharmacophores. Mol Pharm. 2013;10(5):1751-1759

[10] Schleindlin S. Transdermal Drug Delivery: Past, Present, Future. Molecular Interventions. Pharm and Pharmacol. 2004;4(6):308-312.

[11] Tan T. 2008. Kondroitin. [accessed at $11 \mathrm{Feb}$ 2012]. Available at: [http:// www.painrelief.com.sg/id/category/ chondroitin.html]
[12] Zhang W, Nuki G, Moskowitz RW, Abramson S, Altman RD, Arden NK. et al. OARSI recommendations for the management of hip and knee osteoarthritis Part III: changes in evidence following systematic cumulative update of research published through January 2009. Osteoarthritis Cartilage. 2010;18(4):476-499

[13] Zhang W, Moskowitz RW, Nuki G, Abramson S, Altman RD, Arden $\mathrm{N}$. et al. OARSI recommendations for the management of hip and knee osteoarthritis, Part II: OARSI evidence-based, expert consensus guidelines. Osteoarthritis Cartilage. 2008:16;137-162. 